\title{
IDENTIFIKASI BAHAYA DAN PENILAIAN RISIKO OPERATOR MESIN GERINDA
}

\section{HAZARD IDENTIFICATION AND RISK ASSESSMENT OF GRINDING MACHINE OPERATOR}

\author{
Rofika Anggun Thursina \\ PT. PLN Pusmankon \\ E-mail: rofikaanggun@gmail.com
}

\begin{abstract}
Research in the fabrication unit of PT. Bangun Sarana Baja Gresik to determine hazard identification and risk assessment in grinding machine operators. This research uses Systematic Human Error Reduction and Prediction Approach (SHERPA) to determine error in identify hazard consisting of task stage, error mode, error description, consequence analysis and recovery analysis. The AS/NZS 4360: 2004 standard is used to determine the severity, likelihood and risk matrix scales in assessing risks consisting of frequency analysis, severity analysis, and criticality analysis that results in the level of risk at each stage of the task. Population in this research is all grinding machine operator at PT. Bangun Sarana Baja Gresik which are 60 operators. The sample of this research is as much as 20 grinding machine operators fabrication unit of PT. Bangun Sarana Baja Gresik with purposive sampling technique. Hazard identification on the grinding process such as falling material, unstable material condition, cracked grinding wheel, grinding wheel specifications are incompatible with the grinding machine and vice versa, the cable is flaked, melted, even broken, cracked cable terminal, starter (switch on/off) is damaged, sparks, gram sparks, ergonomic body positions, high speed grinding wheels, welding rays, noise and tool hand vibration can result in scratches, abrasions, dislocations, fractures, scratches broken grinding stones, electric shock, pincers, burns, low back pain, sore eyes, hand arm vibration syndrome and carpal tunnel syndrome in the worker's body. Risk assessment for low risk task stage is 6 error descriptions which means acceptable risk and no action required, medium risk is 31 error descriptions which means more alert and corrective action is recommended if cost effective, and high risk is 12 error descriptions which means the risk to be aware and there are actions needed to control the risks.
\end{abstract}

Keywords: grinding, hazard identification, risk assessment

\begin{abstract}
ABSTRAK
Penelitian di unit fabrikasi PT. Bangun Sarana Baja ini bertujuan untuk melakukan identifikasi bahaya dan penilaian risiko pada operator mesin gerinda. Penelitian ini menggunakan Systematic Human Error Reduction and Prediction Approach (SHERPA) untuk menentukan error dalam identifikasi bahaya yang terdiri dari tahap tugas, mode error, deskripsi error, analisis konsekuensi dan analisis pemulihan. Standar AS/NZS 4360: 2004 digunakan untuk menentukan skala severity, likelihood dan risk matrix dalam menilai risiko yang terdiri dari analisis kekerapan, analisis keparahan, dan analisis kekritisan yang menghasilkan tingkat risiko pada masing-masing tahap tugas. Populasi dalam penelitian ini adalah seluruh operator mesin gerinda di PT. Bangun Sarana Baja Gresik yang berjumlah 60 orang. Sampel penelitian ini yaitu sebanyak 20 operator mesin gerinda unit fabrikasi PT. Bangun Sarana Baja Gresik dengan teknik purposive sampling. Identifikasi bahaya pada proses penggerindaan diantaranya material terjatuh, kondisi material tidak stabil, batu gerinda retak, spesifikasi batu gerinda tidak sesuai dengan mesin gerinda dan sebaliknya, bagian luar kabel terkelupas, meleleh, bahkan putus, terminal kabel retak, steker retak, starter (switch on/off) rusak, percikan api, percikan gram, posisi tubuh tidak ergonomis, putaran roda gerinda dengan kecepatan tinggi, sinar las, kebisingan, debu dari hasil penggerindaan dan tool hand vibration yang dapat mengakibatkan luka gores, lecet, dislokasi, patah tulang, tergores pecahan batu gerinda, tersengat arus listrik, terjepit, luka bakar, low back pain, mata berair, hand arm vibration syndrome dan carpal tunnel syndrome pada tubuh pekerja. Penilaian risiko untuk tahap tugas dengan tingkat rendah yaitu 6 deskripsi error yang berarti risiko dapat diterima dan tidak ada tindakan yang diperlukan, risiko sedang yaitu 31 deskripsi error yang berarti lebih waspada dan tindakan perbaikan dianjurkan jika biaya efektif dan risiko tinggi sebanyak 12 deskripsi error yang berarti risiko diwaspadai dan ada tindakan yang diperlukan untuk mengendalikan risikonya.
\end{abstract}

Kata kunci: gerinda, identifikasi bahaya, penilaian risiko

(C2018 IJOSH. Open access under CC BY NC-SA license doi: 10.20473/ijosh.v7i1.2018.30-41 Received 29 July 2017, received in revised form 8 August 2017, Accepted 12 August 2017, Published: 2 February 2018 


\section{PENDAHULUAN}

Setiap tahun ada lebih dari 250 juta kecelakaan di tempat kerja, lebih dari 160 juta pekerja menjadi sakit karena bahaya di tempat kerja, dan 1,2 juta pekerja meninggal akibat kecelakaan dan sakit di tempat kerja (ILO, 2013). Jumlah pekerja di Indonesia hingga Agustus 2015 yaitu 114,8 juta orang (BPS, 2015) dan angka kecelakaan kerjanya hingga akhir tahun 2015 yaitu 105.182 kasus dengan total jumlah kecelakaan kerja setiap tahun mengalami peningkatan hingga 5\% (BPJS Ketenagakerjaan, 2015). Angka kecelakaan kerja di Jawa Timur tahun 2015 pada triwulan I sebanyak 2.180 orang, triwulan II sebanyak 3.099 orang dan triwulan III sebanyak 5.113 orang (Disnakertransduk Jatim, 2015). Angka kecelakaan kerja yang terjadi di Gresik pada periode Januari s/d Mei 2016 sebanyak 1.229 kasus dan sebanyak 16 korban meninggal (BPJS Ketenagakerjaan Gresik, 2016).

PT. Bangun Sarana Baja Gresik merupakan perusahaan yang bergerak di bidang fabrikasi dan konstruksi baja. Proses produksi yang ada dalam perusahaan tersebut dimulai dari tahap drawing, marking-cutting, drilling or punching, assembling, welding, finishing (terdiri dari proses penggerindaan, stamp, dan sandblasting), painting, quality control dan packing. Proses produksi yang demikian tentunya membutuhkan peralatan dan mesin yang bisa menimbulkan potensi bahaya. Peralatan dan mesin yang digunakan antara lain mesin las, mesin gerinda, mesin cutting, forklift, mesin drilling or punching, mesin sandblasting, kompresor, mesin plat, mesin press dan overhead crane (OHC). Gambaran aktivitas produksi tersebut berpotensi menimbulkan bahaya dan risiko kecelakaan kerja. Data kecelakaan kerja di PT. Bangun Sarana Baja Gresik tahun 2016 terdapat pada tabel 1.

Kondisi terjadinya kecelakaan kerja di PT. Bangun Sarana Baja Gresik disebabkan oleh banyak faktor salah satunya ialah kelalaian manusia (human error). Human error dapat didefinisikan suatu keputusan, tindakan yang mengurangi atau potensial untuk mengurangi efektivitas keamanan atau performansi suatu sistem (Mc Cormick, 1993). Penyebab human error yang terjadi di antaranya karena tidak dijalankannya prosedur yang ada dan disebabkan oleh kelalaian dari operator mesin. Apabila hal tersebut tidak segera dikendalikan maka akan timbul potensi kecelakaan yang semakin besar. Oleh karena itu kondisi yang diakibatkan oleh human error tersebut harus dapat diminimalisasi
Tabel 1. Kecelakaan Kerja di PT. Bangun Sarana Baja Tahun 2016

\begin{tabular}{lc}
\hline \multicolumn{1}{c}{ Kecelakaan Kerja } & Jumlah (orang) \\
\hline Rembes & 169 \\
Kena Gram & 90 \\
Lecet & 33 \\
Luka Terbuka & 9 \\
Luka Bakar & 9 \\
Terjepit & 6 \\
Tergores & 3 \\
Tertimpa Material & 2 \\
Patah Tulang & 2 \\
Kepala Bocor & 1 \\
Meninggal Dunia & 0 \\
\hline
\end{tabular}

Sumber: Klinik PT. Bangun Sarana Baja Gresik

dengan melakukan perbaikan yang diawali dengan melakukan identifikasi human error. Identifikasi human error di unit fabrikasi PT. Bangun Sarana Baja Gresik ini akan dilakukan dengan menggunakan metode Systematic Human Error Reduction and Prediction Approach (SHERPA) untuk mengetahui human error yang mungkin terjadi pada saat menggunakan mesin gerinda sehingga dapat dilakukan penilaian terhadap risiko yang akan timbul dan dilakukan pengendalian untuk menghindari risiko kecelakaan kerja.

Systematic Human Error Reduction and Prediction Approach (SHERPA) sebagai salah satu metode identifikasi human error yang paling sering diaplikasikan dan memiliki beberapa keunggulan jika dibandingkan metode lain diantaranya merupakan sebuah teknik untuk memprediksi human error yang mungkin terjadi dengan mengidentifikasi langkah-langkah pekerjaan yang dilakukan sehingga dapat menganalisis solusi-solusi potensial untuk mengatasi error dalam cara yang terstruktur. Beberapa kelebihan yang dimiliki oleh Systematic Human Error Reduction and Prediction Approach (SHERPA) menurut Stanton (2002) yaitu prosedur penggunaannya terstruktur dan komprehensif sehingga mudah digunakan, taksonomi membantu analisis dengan tepat dalam mengidentifikasi error yang potensial, data dapat diandalkan dan valid, dan strategi pengurangan error ditawarkan sebagai bagian dari analisis dalam rangka memprediksi error. Systematic Human Error Reduction and Prediction Approach (SHERPA) adalah metode yang memiliki konsistensi dalam mengidentifikasi 
error berdasarkan langkah-langkah yang sistematis dengan Hierarchy Task Analysis (HTA) sebagai input data yang akan diolah. Task yang akan dianalisa dibreakdown terlebih dahulu, kemudian dari setiap task level dasar akan diprediksi human error yang terjadi sehingga dapat direduksi dan diberikan solusi. Systematic Human Error Reduction and Prediction Approach (SHERPA) lebih cocok diterapkan untuk error yang berhubungan dengan keahlian dan kebiasaan manusia, lebih detail dan konsisten dalam identifikasi error (Kirwan, 1994).

Beberapa penelitian sebelumnya yang menggunakan metode Systematic Human Error Reduction and Prediction Approach (SHERPA) dan menghasilkan pengendalian yang solutif bagi masalah di bidang keselamatan dan kesehatan kerja. Berdasarkan beberapa penelitian yang sudah ada tersebut, penulis tertarik untuk menggunakan metode Systematic Human Error Reduction and Prediction Approach (SHERPA) sebagai tools untuk mengidentifikasi bahaya dan menilai risiko pada operator mesin gerinda dengan dasar keselamatan dan kesehatan kerja (K3) yang disebabkan oleh berbagai faktor, salah satunya human error. Menurut Ramli (2010), kegiatan identifikasi bahaya dan penilaian risiko di tempat kerja mempunyai tujuan untuk meminimalkan kerugian akibat kecelakaan dan sakit, meningkatkan kesempatan atau peluang untuk meningkatkan produksi melalui suasana kerja yang aman, sehat dan nyaman, memotong mata rantai kejadian kerugian akibat kegagalan produksi yang disebabkan kecelakaan dan sakit, serta pencegahan kerugian akibat kecelakaan dan penyakit akibat kerja.

Di unit fabrikasi PT. Bangun Sarana Baja Gresik terdapat beberapa proses fabrikasi. Satu dari beberapa proses di atas terdapat proses penggerindaan dengan menggunakan mesin gerinda tangan. Proses penggerindaan ini dilakukan oleh pekerja yang mengoperasikan mesin gerinda. Gambaran aktivitas produksi tersebut berpotensi menimbulkan bahaya dan risiko kecelakaan kerja. Bahaya dari proses penggerindaan antara lain terkena gram, rembes akibat terkena sinar las, lecet, tergores, percikan api yang mengakibatkan luka bakar, pecahnya batu gerinda, tersengat arus listrik, luka sayat, dislokasi, patah tulang, kebisingan yang dapat mengakibatkan gangguan pendengaran, hand arm vibration syndrome, carpal tunnel syndrome, tremor pada tangan, terjepit material, tersandung material, debu hasil proses penggerindaan yang menyebabkan adanya gangguan pernapasan, penyakit paru (pneumonia, bronkhitis, efusi pleura, edema paru), terkena permukaan material panas.

Berdasarkan data kecelakaan kerja di PT. Bangun Sarana Baja Gresik tahun 2016, pada tabel 2 terdapat 137 dari 324 kecelakaan kerja yang ada adalah kecelakaan kerja di bagian penggerindaan, yang berarti sejumlah $41,35 \%$ dari total keseluruhan kecelakaan kerja yang terjadi. Berdasarkan accident report PT. Bangun Sarana Baja Gresik tahun 2016, kerugian akibat kecelakaan kerja

Tabel 2. Kecelakaan Kerja berdasarkan Spesifikasi Pekerjaan di PT. Bangun Sarana Baja Tahun 2016

\begin{tabular}{lccccccc}
\hline Jenis Pekerjaan & $\begin{array}{c}\text { Terkena } \\
\text { gram }\end{array}$ & $\begin{array}{c}\text { Rembes } \\
\text { (Mata Merah) }\end{array}$ & Tergores & Lecet & $\begin{array}{c}\text { Luka } \\
\text { Bakar }\end{array}$ & $\begin{array}{c}\text { Luka } \\
\text { Terbuka }\end{array}$ & Total \\
\hline Tukang gerinda & 63 & 97 & 5 & 17 & 3 & 2 & 187 \\
Tukang las & 6 & 53 & - & 3 & 4 & - & 66 \\
Tukang setel & 3 & 23 & 2 & 5 & - & - & 33 \\
\hline
\end{tabular}

Sumber: Klinik PT. Bangun Sarana Baja Gresik

Tabel 3. Kecelakaan Kerja berdasarkan Spesifikasi Pekerjaan di PT. Bangun Sarana Baja Tahun 2017

\begin{tabular}{lccccccc}
\hline Jenis Pekerjaan & $\begin{array}{c}\text { Terkena } \\
\text { gram }\end{array}$ & $\begin{array}{c}\text { Rembes } \\
\text { (Mata Merah) }\end{array}$ & Tergores & Lecet & $\begin{array}{c}\text { Luka } \\
\text { Bakar }\end{array}$ & $\begin{array}{c}\text { Luka } \\
\text { Terbuka }\end{array}$ & Total \\
\hline Tukang gerinda & 18 & 21 & 7 & 13 & 1 & 1 & 61 \\
Tukang las & - & 37 & 1 & 3 & - & - & 41 \\
Tukang setel & 2 & 12 & 2 & 4 & - & - & 20 \\
\hline
\end{tabular}

Sumber: Klinik PT. Bangun Sarana Baja Gresik 
pada pekerja bagian penggerindaan yaitu sebesar Rp. 5.725.880,00 (lima juta tujuh ratus dua puluh lima ribu delapan ratus delapan puluh rupiah). Data kecelakaan kerja di bagian penggerindaan PT. Bangun Sarana Baja Gresik tahun 2016 dan bulan Januari s/d Maret tahun 2017 disajikan pada tabel 4 dan tabel 5 .

Tabel 4. Kecelakaan Kerja Operator Mesin Gerinda Unit Fabrikasi PT. Bangun Sarana Baja Tahun 2016

\begin{tabular}{lc}
\hline \multicolumn{1}{c}{ Kecelakaan Kerja } & Jumlah (orang) \\
\hline Kena Gram & 90 \\
Rembes & 30 \\
Lecet & 14 \\
Tergores & 3 \\
\hline
\end{tabular}

Sumber: Klinik PT. Bangun Sarana Baja Gresik

Tabel 5. Kecelakaan Kerja Operator Mesin Gerinda Unit Fabrikasi PT. Bangun Sarana Baja Bulan Januari s/d Maret 2017

\begin{tabular}{lccc}
\hline \multirow{2}{*}{$\begin{array}{c}\text { Kecelakaan } \\
\text { Kerja }\end{array}$} & \multicolumn{3}{c}{ Jumlah (orang) } \\
\cline { 2 - 4 } & Januari & Februari & Maret \\
\hline Kena Gram & 6 & 5 & 2 \\
Rembes & 3 & 2 & 3 \\
Lecet & 1 & 1 & 0 \\
Tergores & 2 & 0 & 3 \\
\hline
\end{tabular}

Sumber: Klinik PT. Bangun Sarana Baja Gresik

Penelitian ini bertujuan untuk melakukan identifikasi bahaya dan penilaian risiko pada operator mesin gerinda dengan metode Systematic Human Error Reduction and Prediction Approach (SHERPA) di unit fabrikasi PT. Bangun Sarana Baja Gresik.

\section{METODE}

Penelitian ini berdasarkan sifatnya, penelitian ini termasuk dalam penelitian deskriptif yang memiliki tujuan memberikan gambaran objektif terhadap suatu keadaan dengan cara mendeskripsikannya. Berdasarkan waktu, penelitian ini termasuk dalam penelitian cross sectional karena variabel objek penelitian dikumpulkan dan dianalisis pada satu waktu. Berdasarkan metode pengumpulan data, penelitian ini termasuk dalam penelitian observasional (Notoatmodjo, 2005). Penelitian ini berlokasi di PT. Bangun Sarana Baja Jalan Mayjend Sungkono XII No. 8, Ngargosari, Kebomas, Kabupaten Gresik, Jawa Timur pada bulan Mei s/d Juni 2017. Populasi dalam penelitian ini adalah seluruh pekerja di PT. Bangun Sarana Baja Gresik. Sampel penelitian ini yaitu sebanyak 20 operator mesin gerinda unit fabrikasi PT. Bangun Sarana Baja Gresik dengan teknik purposive sampling. Sampling purposive adalah teknik penentuan sampel dengan pertimbangan tertentu (Sugiyono, 2006). Pemilihan sampel ditentukan oleh peneliti dengan bantuan pertimbangan dari pihak Departemen Health Safety Environment (HSE) utamanya HSE officer yang paham mengenai karakteristik pekerjanya di lapangan sehingga didapatkan sampel sejumlah 20 orang.

Variabel dalam penelitian ini adalah identifikasi bahaya (tahap tugas, mode error, deskripsi error, analisis konsekuensi, analisis pemulihan) dan penilaian risiko (analisis kekerapan, analisis keparahan, analisis kekritisan). Pengumpulan data dilakukan setelah responden diberi penjelasan mengenai Penjelasan Sebelum Persetujuan (PSP) dan informed consent. Data yang dikumpulkan terdiri dari data primer dan data sekunder.

Data primer dikumpulkan melalui dua cara yaitu melalui observasi dan wawancara. Pengamatan dilakukan secara langsung pada operator mesin gerinda unit fabrikasi PT. Bangun Sarana Baja Gresik. Wawancara dilakukan dengan beberapa pihak terkait yaitu pekerja di bagian penggerindaan, manajer departemen Health Safety Environment (HSE), kabag warehouse, kabag mekanik, dan manajer produksi. Wawancara kepada operator mesin gerinda dilakukan untuk memperoleh data terkait tahapan proses pekerjaan menggerinda. Wawancara kepada manajer departemen Health Safety Environment (HSE) dilakukan untuk memperoleh data terkait safety work permit melepaskan safety guard pada mesin gerinda untuk pekerjaan menggerinda pada lekukan baja. Wawancara kepada kabag departemen warehouse dilakukan untuk memperoleh data terkait penyediaan batu gerinda yang sesuai dengan spesifikasinya. Wawancara kepada kabag mekanik dilakukan untuk memperoleh data terkait pemeliharaan dan perbaikan mesin gerinda. Wawancara kepada manajer produksi dilakukan untuk memperoleh data terkait Standard Operasional Prosedur (SOP) dan Instruksi Kerja (IK) finishing utamanya pekerjaan menggerinda. 
Tabel 6. Mode Error dan Deskripsi Error pada Metode SHERPA

\begin{tabular}{|c|c|}
\hline $\begin{array}{l}\text { Mode } \\
\text { Error }\end{array}$ & Deskripsi Error \\
\hline \multicolumn{2}{|c|}{ Kesalahan tindakan/aksi } \\
\hline A1 & Tindakan/aksi terlalu panjang/pendek \\
\hline A2 & Tindakan/aksi tidak pada saat yang tepat \\
\hline A3 & Tindakan/aksi dalam arah yang salah \\
\hline A4 & $\begin{array}{l}\text { Tindakan/aksi terlalu sedikit atau terlalu } \\
\text { banyak }\end{array}$ \\
\hline A5 & Urutan tindakan/aksi yang tidak benar \\
\hline A6 & $\begin{array}{l}\text { Tindakan/aksi benar di objek yang salah } \\
\text { Salah tindakan/aksi pada objek yang } \\
\text { benar }\end{array}$ \\
\hline A7 & Tindakan/aksi dihilangkan \\
\hline A8 & Tindakan/aksi tidak lengkap \\
\hline A9 & Salah tindakan/aksi pada objek yang \\
\hline A 10 & salah \\
\hline \multicolumn{2}{|c|}{ Kesalahan memeriksa } \\
\hline $\mathrm{C} 1$ & Pemeriksaan dihilangkan \\
\hline $\mathrm{C} 2$ & Pemeriksaan tidak lengkap \\
\hline $\mathrm{C} 3$ & Pemeriksaan benar di objek yang salah \\
\hline $\mathrm{C} 4$ & Salah memeriksa di objek yang benar \\
\hline C5 & Pemeriksaan tidak pada saat yang tepat \\
\hline C6 & Salah memeriksa pada objek yang salah \\
\hline \multicolumn{2}{|c|}{$\begin{array}{l}\text { Kesalahan retrieval (mendapatkan informasi/ } \\
\text { keterangan) }\end{array}$} \\
\hline $\mathrm{R} 1$ & Informasi tidak diperoleh \\
\hline $\mathrm{R} 2$ & Salah informasi yang diperoleh \\
\hline R3 & Informasi yang didapatkan tidak lengkap \\
\hline \multicolumn{2}{|c|}{ Kesalahan komunikasi } \\
\hline I1 & $\begin{array}{l}\text { Pesan tidak dikomunikasikan/ } \\
\text { disampaikan }\end{array}$ \\
\hline $\mathrm{I} 2$ & $\begin{array}{l}\text { Pesan yang dikomunikasikan/ } \\
\text { disampaikan salah }\end{array}$ \\
\hline I3 & Pesan yang disampaikan tidak lengkap \\
\hline \multicolumn{2}{|c|}{ Kesalahan pemilihan } \\
\hline $\mathrm{S} 1$ & Seleksi/pilihan dihilangkan \\
\hline $\mathrm{S} 2$ & Salah membuat pilihan \\
\hline
\end{tabular}

Data sekunder diperoleh dari data perusahaan yang meliputi data tentang profil perusahaan, Standard Operasional Prosedur (SOP) dan Instruksi Kerja (IK) Finishing dan data kecelakaan kerja. Instrumen yang digunakan dalam pengumpulan data terdiri atas lembar observasi dan lembar wawancara. Data yang diperoleh melalui observasi dan wawancara selanjutnya akan dianalisis menggunakan metode Systematic Human Error Reduction and Prediction Approach (SHERPA) yang secara garis besar terdiri atas identifikasi bahaya (tahap tugas, mode error, deskripsi error, analisis konsekuensi, analisis pemulihan), dan penilaian risiko (analisis kekerapan, analisis keparahan, analisis kekritisan).

\section{HASIL}

Tahap tugas memakai pakaian kerja menghasilkan mode error yaitu S2 yang berarti salah memilih pakaian kerja. Analisis konsekuensinya yaitu bagian tubuh yang terbuka terkena percikan api, kulit kemerahan, luka bakar, terkena permukaan material yang panas, lecet, lengan tergores material, lengan tergores pecahan batu gerinda. Analisis pemulihannya yaitu memakai pakaian kerja yang berlengan panjang.

Tahap tugas memakai sepatu safety menghasilkan mode error yaitu A8 yang berarti tidak memakai sepatu safety. Analisis konsekuensi yang dihasilkan yaitu tertimpa material, lecet, luka gores, dislokasi, patah tulang. Analisis pemulihan yang dihasilkan yaitu memakai sepatu safety.

Tahap tugas memakai helm menghasilkan mode error A3 yang berarti tindakan dalam arah yang salah. Analisis konsekuensi yang dihasilkan yaitu tertimpa material, luka terbuka sehingga menghasilkan analisis pemulihan berupa merubah helm yang dipakai secara terbalik. Mode error lain yang dihasilkan dari tahap ini yaitu A8 yang berarti tidak memakai helm. Analisis konsekuensi yang dihasilkan yaitu tertimpa material, luka terbuka sehingga menghasilkan analisis pemulihan berupa memakai helm.

Tahap tugas memakai pelindung telinga yaitu ear plug menghasilkan mode error A7 yang berarti salah menggunakan pelindung telinga. Analisis konsekuensi yang dihasilkan yaitu penurunan fungsi pendengaran, kebisingan, gangguan pendengaran sehingga menghasilkan analisis pemulihan berupa menggunakan pelindung telinga yang disediakan yaitu ear plug. Mode error lain yang dihasilkan dari tahap ini yaitu A8 yang berarti tidak memakai ear plug. Analisis konsekuensi yang dihasilkan yaitu kebisingan, penurunan fungsi pendengaran, gangguan pendengaran sehingga menghasilkan analisis pemulihan berupa memakai ear plug.

Tahap tugas memakai masker menghasilkan mode error A7 yang berarti salah menggunakan masker. Analisis konsekuensi yang dihasilkan yaitu gangguan saluran pernafasan akibat debu dari proses penggerindaan sehingga menghasilkan analisis pemulihan berupa menggunakan masker yang sesuai yaitu masker kain. Mode error lain 
yang dihasilkan dari tahap ini yaitu A8 yang berarti tidak memakai masker. Analisis konsekuensi yang dihasilkan gangguan saluran pernafasan akibat debu dari proses penggerindaan, penyakit paru (pneumonia, bronkhitis, efusi pleura, edema paru) sehingga menghasilkan analisis pemulihan berupa memakai masker kain.

Tahap tugas memakai face shield menghasilkan mode error yaitu A8 yang berarti tidak memakai face shield. Analisis konsekuensi yang dihasilkan yaitu area wajah terutama mata rawan terkena percikan gram gerinda, percikan gram yang tidak segera diambil akan menyebabkan iritasi mata, penurunan fungsi penglihatan, wajah terkena percikan api dari proses penggerindaan, terkena pecahan batu gerinda yang terpental ke wajah, leher tergores pecahan batu gerinda. Analisis pemulihan yang dihasilkan yaitu memakai face shield.

Tahap tugas memakai sarung tangan menghasilkan mode error yaitu A8 yang berarti tidak memakai sarung tangan. Analisis konsekuensi yang dihasilkan yaitu lecet, tergores material, luka terbuka, tergores pecahan batu gerinda, terkena percikan api, terkena percikan gram gerinda, luka bakar, terkena permukaan material panas, tangan, terjepit material, getaran, hand arm vibration, carpal turnel syndrom, tremor pada tangan. Analisis pemulihan yang dihasilkan yaitu memakai sarung tangan. Mode error lain yang dihasilkan yaitu A9 yang berarti tidak memakai sarung tangan secara lengkap pada kedua tangan. Analisis konsekuensi yang dihasilkan yaitu tergores batu gerinda yang berputar, lecet, luka terbuka, terkena percikan api, terkena percikan gram gerinda, luka bakar, terkena permukaan material panas, getaran, hand arm vibration syndrom, carpal tunnel syndrom, tremor pada tangan. Analisis pemulihan yang dihasilkan yaitu melengkapi pemakaian sarung tangan pada salah satu tangan.

Tahap tugas memeriksa safety device (wheel guard) mesin gerinda menghasilkan mode error yaitu $\mathrm{C} 1$ yang berarti tidak memeriksa safety device (wheel guard) pada mesin gerinda. Analisis konsekuensi yang dihasilkan yaitu apabila batu gerinda pecah maka bagian tubuh berisiko terkena pecahan batu gerinda, pecahan batu gerinda mengenai area wajah dan leher, percikan gram gerinda, percikan api dari proses penggerindaan dan tidak ada pemulihan yang bisa dilakukan.

Tahap tugas memeriksa pegangan mesin gerinda menghasilkan mode error yaitu $\mathrm{C} 1$ yang berarti tidak memeriksa pegangan mesin gerinda. Analisis konsekuensi yang dihasilkan yaitu getaran, tremor pada tangan, hand arm vibration syndrom, carpal tunnel syndrom, baut pada pegangan body mesin gerinda terlepas dan tidak ada pemulihan yang bisa dilakukan. Mode error lain yang dihasilkan yaitu C5 yang berarti pemeriksaan pegangan mesin gerinda dilakukan pada saat yang tidak tepat. Analisis konsekuensi yang dihasilkan yaitu terkena batu gerinda yang berputar, tergores batu gerinda, luka terbuka, lecet, getaran, tremor pada tangan, hand arm vibration carpal tunnel syndrom serta tidak ada pemulihan yang bisa dilakukan.

Tahap tugas memeriksa pegangan tambahan mesin gerinda menghasilkan mode error yaitu $\mathrm{C} 1$ yang berarti tidak ada pemeriksaan pada pegangan tambahan mesin gerinda. Analisis konsekuensi yang dihasilkan yaitu getaran, tremor pada tangan, hand arm vibration, carpal tunnel syndrom, mesin gerinda terlepas dari pegangan pada body mesin dan tidak ada pemulihan yang bisa dilakukan.

Tahap tugas memeriksa kondisi kabel menghasilkan mode error yaitu $\mathrm{C} 1$ yang berarti tidak ada pemeriksaan pada kabel. Analisis konsekuensi yang dihasilkan yaitu kabel terkelupas, kabel terbuka, tersengat arus listrik dan tidak ada pemulihan yang bisa dilakukan. Mode error lain yang dihasilkan yaitu $\mathrm{C} 2$ yang berarti pemeriksaan pada kabel mesin gerinda tidak lengkap. Analisis konsekuensi yang dihasilkan yaitu tersangkut kabel, tersandung kabel, tersengat arus listrik. Tidak ada pemulihan yang bisa dilakukan. Mode error lain yang juga terjadi dalam tahap tugas ini adalah $\mathrm{C} 5$ yang berarti pemeriksaan kabel mesin gerinda dilakukan pada saat yang tidak tepat. Analisis konsekuensi yang dihasilkan yaitu tersangkut kabel, tersandung kabel, tersengat arus listrik. Analisis pemulihan yang bisa dilakukan yaitu memeriksa kabel setelah mencabut steker.

Tahap tugas memeriksa terminal kabel (stop kontak) menghasilkan mode error yaitu $\mathrm{C} 1$ yang berarti tidak ada pemeriksaan pada terminal kabel. Analisis konsekuensi yang dihasilkan yaitu terminal kabel retak, terminal kabel pecah, tersengat arus listrik serta tidak ada pemulihan yang bisa dilakukan. Mode error lain yang juga terjadi dalam tahap tugas ini adalah $\mathrm{C} 5$ yang berarti pemeriksaan terminal kabel mesin gerinda dilakukan pada saat yang tidak tepat. Analisis konsekuensi yang dihasilkan yaitu tersengat arus listrik. Analisis pemulihan yang bisa dilakukan yaitu memeriksa terminal kabel setelah arus listrik dimatikan.

Tahap tugas memeriksa starter (switch on off) menghasilkan mode error yaitu $\mathrm{C} 1$ yang berarti tidak 
ada pemeriksaan pada starter (switch on off) mesin gerinda. Analisis konsekuensi yang dihasilkan yaitu starter (switch on off) tidak berfungsi, starter (switch on off) rusak bahkan tidak ada, tersengat arus listrik. Tidak ada pemulihan yang bisa dilakukan. Mode error lain yang juga terjadi dalam tahap tugas ini adalah C5 yang berarti pemeriksaan starter (switch on off) dilakukan pada saat yang tidak tepat. Analisis konsekuensi yang dihasilkan yaitu tersengat arus listrik, terkena putaran batu gerinda yang masih terpasang. Analisis pemulihan yang bisa dilakukan yaitu memeriksa starter (switch on off) setelah steker dicabut dari terminal kabel.

Tahap tugas memeriksa kondisi baut mesin gerinda menghasilkan mode error yaitu $\mathrm{C} 1$ yang berarti tidak ada pemeriksaan pada baut mesin gerinda. Analisis konsekuensi yang dihasilkan yaitu getaran pada body mesin gerinda, baut mesin gerinda terlepas. Tidak terdapat pemulihan yang bisa dilakukan. Mode error lain yang juga terjadi dalam tahap tugas ini adalah $\mathrm{C} 5$ yang berarti pemeriksaan pada baut mesin gerinda dilakukan pada saat yang tidak tepat. Analisis konsekuensi yang dihasilkan yaitu terkena getaran mesin gerinda, tergores batu gerinda. Analisis pemulihan yang bisa dilakukan yaitu memeriksa baut mesin gerinda setelah mematikan tombol starter (switch on off) dan mencabut steker.

Tahap tugas memeriksa label mesin gerinda menghasilkan mode error yaitu $\mathrm{C} 1$ yang berarti tidak ada pemeriksaan pada label mesin gerinda. Analisis konsekuensi yang dihasilkan yaitu tidak tertulis spesifikasi kecepatan (RPM) mesin gerinda sehingga akan menyebabkan batu gerinda pecah apabila kecepatan (RPM) nya tidak sesuai atau diatas kecepatan (RPM) batu gerinda. Tidak terdapat pemulihan yang bisa dilakukan.

Tahap tugas memeriksa batu gerinda menghasilkan mode error yaitu $\mathrm{C} 1$ yang berarti tidak ada pemeriksaan pada batu gerinda. Analisis konsekuensi yang dihasilkan yaitu spesifikasi ukuran, fungsi, kecepatan (RPM) batu gerinda tidak sesuai dengan mesin gerinda, salah menentukan batu gerinda, batu gerinda retak, batu gerinda pecah. Tidak terdapat pemulihan yang bisa dilakukan. Mode error lain yang juga terjadi dalam tahap tugas ini yaitu $\mathrm{C} 2$ yang berarti pemeriksaan batu gerinda tidak lengkap. Analisis konsekuensi yang dihasilkan yaitu spesifikasi ukuran, fungsi, kecepatan (RPM) batu gerinda tidak sesuai dengan mesin gerinda, batu gerinda retak sehingga apabila dioperasikan akan pecah dan mengenai bagian tubuh pekerja.
Tidak terdapat pemulihan yang bisa dilakukan. Mode error lain yang juga terjadi yaitu C5 yang berarti pemeriksaan pada batu gerinda dilakukan pada saat yang tidak tepat. Analisis konsekuensi yang dihasilkan yaitu tergores batu gerinda, lecet. Analisis pemulihan yang dilakukan yaitu memeriksa batu gerinda dengan mematikan tombol starter (switch on off) kemudian mencabut steker. Mode error yang juga terjadi yaitu R2 yang berarti salah informasi yang diperoleh mengenai batu gerinda. Analisis konsekuensi yang dihasilkan yaitu salah mengambil batu gerinda, batu gerinda tidak sesuai spesifikasi mesin gerinda. Tidak terdapat pemulihan yang bisa dilakukan. Mode error berikutnya yang juga terjadi yaitu $\mathrm{S} 2$ yang berarti salah memilih batu gerinda. Analisis konsekuensi yang dihasilkan yaitu spesifikasi ukuran batu gerinda tidak sesuai dengan mesin gerinda, kecepatan (RPM) mesin gerinda tidak sesuai dengan kecepatan (RPM) batu gerinda, salah menentukan batu gerinda yang sesuai dengan fungsi penggunaannya. Analisis pemulihan yang dilakukan yaitu mengganti dengan batu gerinda yang sesuai dengan spesifikasi.

Tahap tugas memeriksa mur pengencang batu gerinda menghasilkan mode error yaitu $\mathrm{C} 1$ yang berarti tidak memeriksa mur pengencang batu gerinda. Analisis konsekuensi yang dihasilkan yaitu batu gerinda lepas dan terlempar mengenai bagian tubuh dan area wajah pekerja. Tidak terdapat pemulihan yang bisa dilakukan. Mode error lain yang juga terjadi dalam tahap tugas ini yaitu C5 yang berarti pemeriksaan mur pengencang batu gerinda tidak pada saat yang tepat. Analisis konsekuensi yang dihasilkan yaitu luka terbuka, tergores batu gerinda. Analisis pemulihan yang dilakukan yaitu memeriksa mur pengencang batu gerinda setelah mematikan tombol starter (switch on off) dan mencabut steker. Mode error lain yang juga terjadi yaitu $\mathrm{C} 6$ yang berarti salah memeriksa mur pengencang batu gerinda di tempat yang bukan letak dari mur pengencang tersebut. Analisis konsekuensi yang dihasilkan yaitu mur pengencang tidak kencang dan presisi terhadap batu gerinda akibatnya putarannya tidak maksimal saat menggerinda dan batu bisa terlepas mengenai tubuh pekerja. Tidak terdapat analisis pemulihan yang bisa dilakukan.

Tahap tugas memeriksa kecepatan (RPM) mesin sesuai dengan kecepatan (RPM) batu gerinda/kecepatan (RPM) batu gerinda lebih besar dari kecepatan (RPM) mesin gerinda menghasilkan mode error yaitu $\mathrm{C} 1$ yang berarti tidak ada pemeriksaan pada kecepatan (RPM) mesin gerinda 
dan kecepatan (RPM) batu gerinda. Analisis konsekuensi yang dihasilkan yaitu batu gerinda pecah dan bisa mengenai tubuh, area wajah maupun leher pekerja. Tidak terdapat pemulihan yang bisa dilakukan. Mode error lain yang terjadi dalam tahap tugas ini yaitu $\mathrm{C} 2$ yang berarti pemeriksaan pada kecepatan (RPM) mesin gerinda dan kecepatan (RPM) batu gerinda tidak dilakukan secara lengkap. Analisis konsekuensi yang dihasilkan yaitu batu gerinda pecah dan bisa mengenai tubuh, area wajah maupun bagian leher pekerja. Tidak terdapat pemulihan yang bisa dilakukan. Mode error lain yang juga terjadi dalam tahap tugas ini yaitu $\mathrm{C} 4$ yang berarti salah memeriksa kecepatan (RPM) pada label yang terdapat di mesin maupun batu gerinda. Analisis konsekuensi yang dihasilkan yaitu batu gerinda pecah dan bisa mengenai tubuh, area wajah maupun bagian leher pekerja. Tidak terdapat pemulihan yang bisa dilakukan.

Tahap tugas memeriksa kunci pemasangan dan kunci pembuka mur pengencang batu gerinda menghasilkan mode error yaitu $\mathrm{C} 1$ yang berarti tidak ada pemeriksaan pada kunci pemasangan dan kunci pembuka mur pengencang batu gerinda. Analisis konsekuensi yang dihasilkan yaitu pemasangan batu gerinda tidak kencang dan tidak presisi sehingga batu gerinda bisa terlepas saat proses penggerindaan akibatnya bisa terlempar mengenai tubuh pekerja, tangan terkena palu akibat memasang mur pengencang dengan palu. Tidak terdapat pemulihan yang bisa dilakukan.

Tahap tugas memastikan material yang akan digerinda stabil dan tidak goyang menghasilkan mode error yaitu $\mathrm{C} 1$ yang berarti tidak ada pemeriksaan pada material yang akan digerinda. Analisis konsekuensi yang dihasilkan yaitu material terjatuh, tertimpa material, dislokasi, patah tulang. Tidak terdapat pemulihan yang bisa dilakukan. Mode error lain yang terjadi yaitu C5 yang berarti pemeriksaan terhadap material yang akan digerinda dilakukan pada saat yang tidak tepat. Analisis konsekuensi yang dihasilkan yaitu terkena material panas, material terjatuh, tergores material, tertimpa material, lecet. Tidak terdapat pemulihan yang bisa dilakukan.

Tahap tugas memastikan menancapkan steker ke terminal kabel menghasilkan mode error yaitu A5 yang berarti urutan tindakan yang tidak benar. Analisis konsekuensi yang dihasilkan yaitu steker retak, steker rusak, tersengat arus listrik. Analisis pemulihan yang dilakukan yaitu mencabut steker dari terminal kabel.
Tahap tugas menyalakan mesin gerinda (switch on) menghasilkan mode error yaitu A5 yang berarti urutan tindakan yang tidak benar. Analisis konsekuensi yang dihasilkan yaitu swtich on rusak, tersengat arus listrik. Analisis pemulihan yang dilakukan yaitu menekan tombol off (switch off).

Tahap tugas mencoba mengoperasikan mesin gerinda (testing) menghasilkan mode error yaitu A8 yang berarti tidak ada tindakan untuk mencoba mengoperasikan mesin gerinda (testing). Analisis konsekuensi yang dihasilkan yaitu terlempar batu gerinda yang terlepas akibat mur pengencang tidak presisi dan tidak kencang, getaran, kebisingan. Tidak terdapat pemulihan yang bisa dilakukan.

Tahap tugas mulai menggerinda menghasilkan mode error yaitu A1 yang berarti menggerinda terlalu lama. Analisis konsekuensi yang dihasilkan yaitu panas pada mesin gerinda, tremor pada tangan, getaran, kebisingan, hand arm vibration, carpal tunnel syndrom, awkward body position, low back pain, nyeri pada otot, sendi maupun tulang. Tidak terdapat pemulihan yang bisa dilakukan. Mode error lain yang terjadi yaitu A3 yang berarti menggerinda dalam arah yang salah. Analisis konsekuensi yang dihasilkan yaitu terkena percikan api, terkena percikan gram gerinda, terkena sinar las dari proses pengelasan, mata berair (rembes), terkena pecahan batu gerinda. Tidak terdapat pemulihan yang bisa dilakukan. Mode error lain yang juga terjadi diantaranya A5 yang berarti urutan tahapan menggerinda yang tidak benar. Analisis konsekuensi yang dihasilkan yaitu terkena percikan gram gerinda, terkena pecahan batu gerinda, tergores material, tertimpa material, tersengat arus listrik. Tidak terdapat pemulihan yang bisa dilakukan. Mode error lain yang juga terjadi yaitu R3 yang berarti informasi yang diperoleh tidak lengkap. Analisis konsekuensi yang dihasilkan yaitu terdapat kesalahan dalam menggerinda. Tidak terdapat pemulihan yang bisa dilakukan.

Tahap tugas mematikan mesin gerinda (switch off) menghasilkan mode error yaitu A5 yang berarti urutan tindakan yang tidak benar. Analisis konsekuensi yang dihasilkan yaitu tersengat arus listrik, mesin gerinda tiba-tiba menyala dan bisa menyebabkan luka gores, lecet. Tidak terdapat pemulihan yang bisa dilakukan. Mode error lain yang terjadi yaitu A8 yang berarti tidak ada tindakan mematikan mesin gerinda (switch off). Analisis konsekuensi yang dihasilkan yaitu mesin tiba-tiba menyala dan mengenai bagian tubuh pekerja, tombol (switch off) rusak, luka gores, luka terbuka. Analisis 
pemulihan yang dilakukan yaitu menekan tombol off (switch off).

Tahap tugas mencabut steker dari terminal kabel menghasilkan mode error yaitu A5 yang berarti urutan tindakan yang tidak benar. Analisis konsekuensi yang dihasilkan yaitu tersengat arus listrik, tersangkut kabel. Tidak terdapat pemulihan yang bisa dilakukan. Mode error lain yang terjadi yaitu $\mathrm{A} 8$ yang berarti tidak ada tindakan mencabut steker dari terminal kabel. Analisis konsekuensi yang dihasilkan yaitu steker retak, steker rusak, tersengat arus listrik, tersandung kabel, mesin tibatiba menyala dan mengenai bagian tubuh pekerja, luka gores, lecet. Analisis pemulihan yang dilakukan yaitu mencabut steker dari terminal kabel.

\section{PEMBAHASAN}

\section{Identifikasi Bahaya}

Beberapa bahaya yang berpotensi menimbulkan kecelakaan kerja, masalah kesehatan maupun penyakit akibat kerja di unit fabrikasi PT. Bangun Sarana Baja Gresik yaitu terkena percikan gram gerinda, terkena percikan api, terkena pecahan batu gerinda, terkena sinar las dari proses pengelasan, terkena permukaan material yang panas, tersengat arus listrik, getaran, kebisingan, posisi tubuh tidak ergonomis, debu dari proses penggerindaan, tertimpa material, terlepasnya batu gerinda saat beroperasi, dan tergores batu gerinda.

Terkena percikan gram gerinda. Hal tersebut terjadi pada proses penggerindaan pada baja sehingga dihasilkan butiran baja yang berukuran kecil yang disebut dengan gram. Gram gerinda ini bisa masuk ke bagian tubuh yang terbuka saat bekerja, misal telinga, mata, mulut. Mata adalah salah satu bagian yang paling sering terkena percikan gram gerinda sehingga harus segera ditangani dengan mengambil gram gerinda tersebut. Jika gram ini dibiarkan hingga beberapa hari maka akan menyebabkan iritasi mata, bahkan penurunan fungsi penglihatan.

Terkena percikan api. Hal tersebut terjadi pada proses penggerindaan akibat terjadi gesekan antara batu gerinda dengan baja sehingga menimbulkan percikan api yang terlihat seperti bunga api. Apabila mengenai kulit maka akan membuat kulit berwarna kemerahan dan jika dibiarkan dalam waktu yang lama maka akan ada bintil-bintil kecil berwarna merah kecoklatan menyerupai luka bakar.
Terkena pecahan batu gerinda yang dapat terpental mengenai area wajah, leher, atau bagian tubuh lainnya sehingga bisa menyebabkan adanya lecet, luka gores bahkan luka terbuka. Pecahnya batu gerinda disebabkan oleh beberapa hal diantaranya kondisi batu gerinda yang semula retak kemudian digunakan untuk menggerinda sehingga batu tersebut pecah karena tidak mampu menahan putaran yang terjadi, spesifikasi kecepatan (RPM) batu gerinda tidak sesuai dengan kecepatan (RPM) pada mesin gerinda, spesifikasi kecepatan (RPM) batu gerinda di bawah kecepatan (RPM) pada mesin gerinda, spesifikasi ukuran batu gerinda tidak sesuai dengan spesifikasi ukuran pada mesin gerinda. Misal, mesin gerinda ukuran 5 inch maka ukuran batu gerinda juga harus 5 inch, spesifikasi fungsi batu gerinda tidak sesuai dengan penggunaannya. Batu gerinda yang fungsinya untuk memotong malah digunakan untuk menghaluskan, begitu pula sebaliknya.

Terkena sinar las dari proses pengelasan. Hal tersebut terjadi akibat tidak adanya sekat atau pemisahan antara pekerja di bagian penggerindaan dengan pekerja di bagian pengelasan sehingga menyebabkan pekerja di bagian penggerindaan pun juga mengalami seperti yang terjadi pada pekerja di bagian pengelasan yaitu mata berair (rembes).

Terkena permukaan material yang panas. Hal tersebut terjadi saat baja baru selesai dilas dan selanjutnya akan dilakukan proses penggerindaan. Saat melakukan proses penggerindaan pun juga akan menghasilkan panas yang terjadi akibat adanya gesekan antara batu gerinda yang terbuat dari bahan abrasif dan baja. Apabila bagian tubuh yang terbuka terkena permukaan material yang panas maka akan menyebabkan timbulnya luka bakar.

Tersengat arus listrik. Hal tersebut sangat mungkin terjadi mengingat mesin gerinda ini membutuhkan arus listrik untuk bisa beroperasi. Beberapa keadaan yang dapat menyebabkan pekerja tersengat arus listrik diantaranya kabel terkelupas, kabel terbuka, kabel putus, tersengat arus listrik, tersangkut kabel, tersandung kabel, terminal kabel retak, terminal kabel pecah, starter (switch on off) tidak berfungsi, starter (switch on off) rusak bahkan tidak ada, steker retak, steker rusak.

Getaran yang dihasilkan mesin gerinda berpotensi menimbulkan beberapa masalah kesehatan diantaranya hand arm vibration, carpal tunnel syndrom, tremor pada tangan. Getaran yang terjadi dapat disebabkan oleh beberapa hal diantaranya material yang digerinda besar, tebal dan 
keras sedangkan gerinda yang digunakan berukuran kecil misal 4 inch, pegangan tambahan pada body mesin gerinda tidak terpasang sedangkan material yang digerinda besar, tebal dan keras, baut mesin gerinda tidak kencang bahkan terlepas, putaran batu gerinda yang cepat, dan kombinasi antara putaran batu gerinda yang cepat dengan baut pada mesin gerinda yang terlepas.

Kebisingan yang dihasilkan dari beroperasinya mesin gerinda akan menimbulkan beberapa masalah kesehatan yaitu gangguan pendengaran, penurunan fungsi pendengaran. Posisi tubuh tidak ergonomis dalam menggerinda apabila dilakukan dalam waktu yang cukup lama dan dilakukan dalam posisi awkward body position maka akan berakibat pada munculnya keluhan low back pain, nyeri pada otot, nyeri sendi maupun nyeri tulang.

Debu yang dihasilkan dari proses penggerindaan berisiko menimbulkan adanya gangguan pada saluran dan beberapa penyakit paru diantaranya pneumonia, bronkhitis, efusi pleura, edema paru. Material yang terjatuh dan menimpa pekerja akan berisiko terjadi kecelakaan kerja seperti lecet, luka gores, terjepit material, luka terbuka, dislokasi bahkan patah tulang.

Batu gerinda yang sedang digunakan untuk mengoperasikan mesin gerinda dapat juga terlepas. Hal ini berisiko terhadap terjadinya kecelakaan kerja di antaranya tergores batu gerinda yang terlepas, lecet, luka terbuka. Terlepasnya batu gerinda saat beroperasi dapat disebabkan oleh beberapa hal, diantaranya mur pengencang tidak kencang dan presisi terhadap batu gerinda akibatnya putarannya tidak maksimal saat menggerinda sehingga batu bisa terlepas dari porosnya dan mengenai tubuh pekerja, pemasangan batu gerinda tidak kencang dan tidak presisi sehingga batu gerinda bisa terlepas saat proses penggerindaan.

Batu gerinda dapat menyebabkan adanya luka gores pada tubuh pekerja. Hal ini terjadi karena beberapa hal yaitu mesin gerinda dengan batu gerinda yang masih terpasang tiba-tiba menyala dan mengenai bagian tubuh pekerja. Hal ini dikarenakan tombol switch off yang lupa ditekan dan kondisi steker belum dicabut dari terminal kabel atau steker yang langsung dicabut dari terminal kabel tanpa menekan tombol switch off sehingga apabila steker ditancapkan pada terminal kabel, mesin gerinda akan langsung menyala. Hal ini tentunya berbahaya jika pekerja memegang batu gerinda atau mesin gerinda berada dekat dengan tubuh pekerja. Selain itu, adanya luka gores juga disebabkan karena putaran batu gerinda yang mengenai tubuh pekerja, mesin gerinda yang terlepas dari pegangan dan mengenai pekerja, serta mesin gerinda yang diletakkan tidak pada tempatnya dan cenderung ditinggalkan begitu saja saat jam istirahat tiba.

\section{Penilaian Risiko}

Penilaian risiko yang dilakukan pada beberapa deskripsi error yaitu salah memilih pakaian kerja, salah menggunakan pelindung telinga, masker, tidak ada pemeriksaan pada pegangan dan pegangan tambahan mesin gerinda, pemeriksaan pada baut dilakukan pada saat yang tidak tepat menghasilkan tingkat risiko rendah (low risk). Penilaian risiko yang menghasilkan risiko sedang (medium risk) yaitu pada deskripsi error tidak memakai sepatu safety, ear plug, masker, sarung tangan, tidak memakai sarung tangan secara lengkap pada kedua tangan, pemeriksaan pegangan, kabel, starter, terminal kabel, baut, mur pengencang mesin gerinda dilakukan pada saat yang tidak tepat, tidak ada pemeriksaan pada kabel, starter, terminal kabel, baut, mur pengencang, label, material yang akan digerinda dan kunci pembuka dan pemasangan mur pengencang batu gerinda pada mesin gerinda, pemeriksaan pada kabel dilakukan secara tidak lengkap, salah memeriksa mur pengencang batu gerinda, kecepatan pada label di mesin maupun batu gerinda, urutan tindakan yang tidak benar saat menancapkan steker ke terminal kabel, menyalakan mesin gerinda, mulai menggerinda, mematikan mesin gerinda dan mencabut steker dari terminal kabel, menggerinda terlalu lama, tidak ada tindakan untuk testing mesin gerinda, mencabut steker dari terminal kabel, dan informasi yang diperoleh mengenai gerinda tidak lengkap. Penilaian risiko selanjutnya yang menghasilkan risiko tinggi (high risk) yaitu menggerinda dalam arah yang salah, pemeriksaan terhadap material yang akan digerinda, kecepatan mesin dan batu gerinda, dan batu gerinda dilakukan pada saat yang tidak tepat, tidak memakai face shield, helm, safety guard, memakai helm dalam arah yang salah (terbalik), tidak ada pemeriksaan pada batu gerinda, salah memilih batu gerinda, pemeriksaan pada batu gerinda tidak lengkap, dan tidak ada pemeriksaan pada kecepatan mesin dan batu gerinda. 


\section{SIMPULAN}

Identifikasi bahaya pada proses penggerindaan diantaranya material terjatuh, kondisi material tidak stabil, batu gerinda retak, spesifikasi batu gerinda tidak sesuai dengan spesifikasi mesin gerinda dan sebaliknya, bagian luar kabel terkelupas, meleleh, bahkan putus, terminal kabel retak, steker retak, tombol starter (switch on/off) rusak, percikan api, percikan gram, posisi tubuh tidak ergonomis, putaran roda gerinda dengan kecepatan tinggi, sinar las dari pekerja di sekitarnya, kebisingan, debu dari hasil penggerindaan dan tool hand vibration yang dapat mengakibatkan luka gores, lecet, dislokasi, patah tulang, tergores pecahan batu gerinda, tersengat arus listrik, terjepit, luka bakar, mata atau anggota tubuh lain terkena gram, low back pain, rembes, hand arm vibration syndrome dan carpal tunnel syndrome pada tubuh pekerja. Penilaian risiko untuk tahap tugas dengan tingkat rendah (low risk) yaitu sebanyak 6 deskripsi error yang berarti risiko dapat diterima dan tidak ada tindakan yang diperlukan, risiko sedang (medium risk) 31 deskripsi error yang berarti lebih waspada dan tindakan perbaikan dianjurkan jika biaya efektif. dan risiko tinggi (high risk) sebanyak 12 deskripsi error yaitu menggerinda dalam arah yang salah, pemeriksaan terhadap material yang akan digerinda, kecepatan mesin dan batu gerinda, dan batu gerinda dilakukan pada saat yang tidak tepat, tidak memakai face shield, helm, safety guard, memakai helm dalam arah yang salah (terbalik), tidak ada pemeriksaan pada batu gerinda, salah memilih batu gerinda, pemeriksaan pada batu gerinda tidak lengkap, dan tidak ada pemeriksaan pada kecepatan mesin dan batu gerinda yang berarti risiko diwaspadai dan ada tindakan yang diperlukan untuk mengendalikan risikonya.

\section{DAFTAR PUSTAKA}

BPJS Ketenagakerjaan., 2015. Angka Kecelakaan Kerja di Jawa Timur. Surabaya: BPJS Ketenagakerjaan Jawa Timur. Tersedia dihttp:// disnakertransduk.jatimprov.go.id/disnakerlama/ index.php?option $=$ com_content\&view $=$ frontpa ge\&limitstart=125 [20 Maret 2017].
BPJS Ketenagakerjaan Gresik., 2016. Kecelakaan Kerja di Gresik Tertinggi Se-Jatim. Gresik: BPJS Ketenagakerjaan Gresik. Tersedia di http:// www.jawapos.com/read/2016/06/30/37110/ kecelakaan-kerja-di-gresik-tertinggi-se-jatimlima-bulan-16-korban-meninggal [20 Maret 2017].

BPS., 2015. Penduduk Bekerja Bertambah. Jakarta: Badan Pusat Statistik. Tersedia di http://setkab. go.id/bps-penduduk-bekerja-bertambah-62juta-orangpengangguran-terbuka-turun-581/ [22 Maret 2017].

Dinas Tenaga Kerja Transmigrasi dan Kependudukan Provinsi Jawa Timur., 2015. Angka Kecelakaan Kerja di Jatim Capai Ribuan Orang. Surabaya: Dinas Tenaga kerja Transmigrasi dan Kependudukan Provinsi Jawa Timur. Tersedia di http://kominfo.jatimprov.go.id/read/umum/ disnakertransduk-jatim-angka-kecelakaan-kerjadi-jatim-capai-ribuan-orang [21 Maret 2017].

Ghasemi, M., Nasleseraji, J., 2013. Application of SHERPA to Identify and Prevent Human Error in Control Units of Petrochemichal Industry. International Journal of Occupational Safety and Ergonomics (JOSE).19(2): 203-209.

ILO., 2013. Keselamatan dan Kesehatan Kerja di Tempat Kerja - Sarana untuk Produktivitas. Tersedia di http://www.ilo.org/wcmsp5/groups/ public/---asia/---ro-bangkok/---ilo-jakarta/ documents/publication/wcms_237650.pdf [21 Maret 2017].

Imtiaz, Md., Munsi, A., Nayan, D., Dei, S., 2014. Systematic Human Error Reduction and Prediction Approach While Drilling. International Journal of Scientific and Engineering Research, 5 (12), ISSN 2229-5518.

Kirwan, Barry., 1994. A Guide to Practical Human Reliability Assessment. London: Taylor and Francis.

Klinik PT. Bangun Sarana Baja Gresik., 2016. Laporan Data Kecelakaan Tahun 2016. Gresik: PT Bangun Sarana Baja.

Klinik PT. Bangun Sarana Baja Gresik., 2017. Laporan Data Kecelakaan Tahun 2017. Gresik: PT. Bangun Sarana Baja. 
Mc. Cormick, Ernest J., 1993. Human Factor in Engineering and Design. New Jersey: McGraw-Hill, Inc.

Notoadmodjo, S., 2005. Metodologi Penelitian Kesehatan. Jakarta: PT. Rineka Cipta.

Putro, FC., Helianty, Y., Desrianty, A., 2015, Usulan Perbaikan Sistem Kerja Mesin Bending di PT. X Menggunakan Metode Systematic Human Error Reduction and Prediction Approach (SHERPA). Jurnal Teknik Industri, Institut Teknologi Nasional Bandung, 3 (2), Reka Integra ISSN: 2338-5081.
Ramli, S., 2010. Pedoman Praktis Manajemen Risiko dalam Perspektif K3 OHS Risk Management. Jakarta: PT. Dian Rakyat.

Rahmania, T., Ginting, E., Buchari., 2013, Analisa Human Error dengan Metode SHERPA dan HEART Pada Kecelakaan Kerja di PT XYZ. Jurnal Teknik Industri Fakultas Teknik Universitas Sumatera Utara, 2 (1): PP. 58-65.

Sugiyono. 2006. Statistika untuk Penelitian. Cetakan Ketujuh. Bandung: CV. Alfabeta. 